\title{
BioLink
}

Jurnal Biologi Lingkungan, Industri, Kesehatan

Available online http://ojs.uma.ac.id/index.php/biolink

\section{MACROZOOBENTHOS DIVERSITY AND FUNCTIONAL FEEDING GROUP (FFG) IN BEREMBANG RIVER OF WEST KALIMANTAN}

\section{Wolly Candramila1*, Sisi Marda Lorensa1, Yunike Pristalika1 , \& Junardi²}

${ }^{1}$ Biology Education Study Program, Faculty of Teacher Training and Education, Universitas Tanjungpura, Indonesia

${ }^{2}$ Department of Biology, Faculty of Mathematics and Natural Sciences, Universitas

Tanjungpura, Indonesia

Submited : 11-08-2021; Reviewed :19-09-2021; Accepted : 26-01-2022

*Corresponding author: E-mail : junardi@fmipa.untan.ac.id

\begin{abstract}
This study analyzes macrozoobenthos diversity and functional feeding group in Berembang River, Kubu Raya Regency, West Kalimantan. The obtained macrozoobenthos were identified to the genus level, and their functional feeding group was determined through a literature study. Data on diversity, evenness, and dominance were analyzed descriptively. Diversity $\left(H^{\prime}\right)$ and Evenness (E) of macrozoobenthos in Berembang River were low $\left(H^{\prime}=0.73\right.$ and $\left.E=0.15\right)$ while Dominance $(C)$ was high $(C=0.81)$ as evidenced by a large number of genera Corbicula and Gammarus. Macrozoobenthos functional feeding groups found at both stations can be divided into six categories, namely shredders, gathering collectors, deposit feeders, subsurface deposit feeders, filtering collectors, and scrapers.
\end{abstract}

Keywords: Macrozoobenthos; Diversity; Functional Feeding Group; Water Quality

How to Cite: Candramila, W., Lorensa, S.M., Pristalika, Y., \& Junardi. (2022). Macrozoobenthos Diversity And Functional Feeding Group (FFG) In Berembang River Of West Kalimantan, BioLink: Jurnal Biologi Lingkungan, Industri dan Kesehatan, Vol. 8 (2): Hal. 218-228 


\section{INTRODUCTION}

West Kalimantan is known as the province of thousand rivers. This designation is in line with its geographical condition, which has waters reaching $41 \%$ $(60,396 \mathrm{~km} 2)$ of the total area of West Kalimantan $(147,307 \mathrm{~km} 2)$, which consists of lakes, freshwater swamps, and rivers. Kapuas River is a large river with many watersheds. This river flows from Kapuas Hulu District through several districts until it estuary in two districts namely, Kubu Raya and Mempawah

Berembang River is a small river part of Kapuas watershed in Pontianak City. The results of field observations show that the Berembang River is relied on to meet the water needs for irrigation and the daily use by the surrounding community, including for bathing, washing, and irrigating rice fields and gardens. These activities can produce organic and inorganic waste, which can cause disturbance to biota and will also affect the balance of the river ecosystem. River quality can be seen based on changes in chemical and physical properties and the composition of the biota that live in it. Macrozoobenthos is a group of aquatic animals that have been widely used to assess water quality because it is sedentary and has different tolerances between various taxa (Tampo et al., 2021).
The groups of animals that inhabit the bottom of these waters have varied roles to be used to analyze food webs and changes in river ecosystems. According to Cumming, the Functional Feeding Group (FFG) is a functional approach based on the characteristics possessed by organisms, namely to describe their eating habits (Madomguia et al., 2016). Differences in the environmental zone can result in different FFG patterns of macrozoobenthos (Cabrera et al., 2021). It indicates that changes and differences in environmental conditions can affect interaction patterns within an ecosystem (Mangadze et al., 2019), especially diet and eating patterns. This study was conducted to determine the status of water quality and determine the effects of human activities in Berembang River based on macrozoobenthos diversity and functional feeding group.

\section{MATERIALS AND METHODS}

\section{Sampling}

Sampling was done by purposive sampling technique at two stations with different riparian conditions in Berembang River, Kubu Raya Regency. These differences are used as the basis for sampling at each station, namely riparian with vegetation and riparian without vegetation or human activities. Station 1 
was surrounded by banana and coconut plantations, while Station 2 was located around densely populated residential areas (Figure 1).

Macrozoobenthos samples were taken using an Ekman grab size of 20x20 $\mathrm{cm}^{2}$. Sampling time was carried out in November 2020. A sampling at each station was carried out three times on the left, right, and central banks of the river so that at one station, there were nine sampling points for each station. The substrate sample was filtered through a stratified sieve arranged from $1 \mathrm{~mm}, 0.5 \mathrm{~mm}$, and 0.25 diameter sieve (Hartwell \& Fukuyama, 2015). Macrozoobenthos from the sieve was put into a sample bottle and given as preservative $4 \%$ formalin. The samples were sorted and grouped by class in the laboratory and the preservatives were replaced with 70\% alcohol (Ghosh \& Biswas, 2015).

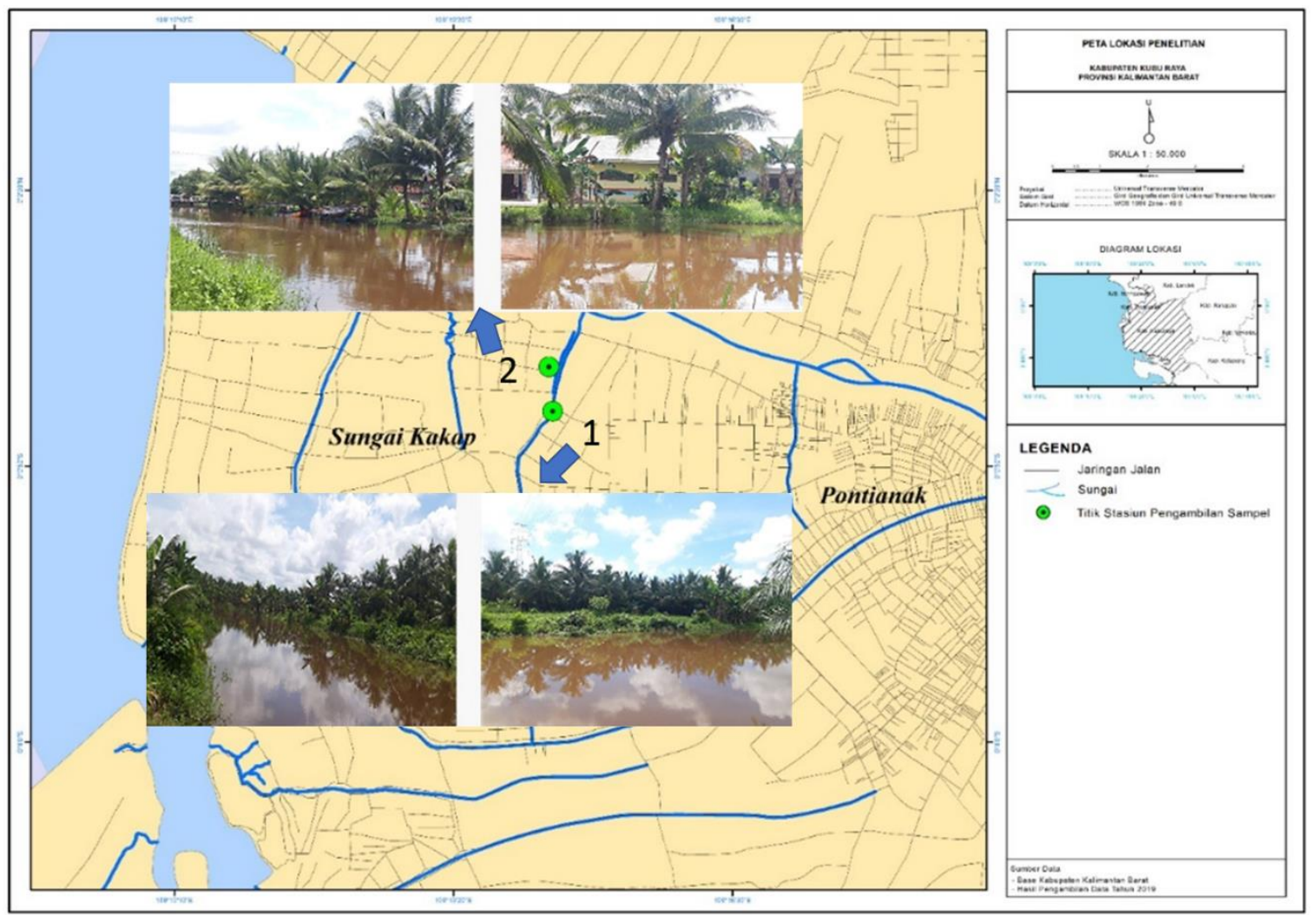

Figure 1. Map of research locations and stations in Berembang River, Kubu Raya Regency, West Kalimantan

Measurement of Physical-Chemical acidity of the water was measured with a

\section{Factors}

Environmental parameters were measured directly on-site (in situ) together with macrozoobenthos sampling. The digital $\mathrm{pH}$ meter by taking a sample of surface water.

\section{Data Identification and Analysis}

Macrozoobenthos identification 
was carried out at the Laboratorium

Terpadu, University of Tanjungpura. Identification was carried out at the genus level, while the macrozoobenthos functional feeding group for each genus used literature (Chen et al., 2020; Ana et al., 2020; Damanik-Ambarita et al., 2016; Pastorino et al., 2020). The data were analyzed descriptively.

Data analysis to calculate the diversity of macrozoobenthos were as follows

a. Individual Abundance/Genus Density

Species abundance (K) of
macrozoobenthos was defined as the number of individual macrozoobenthos per unit area $\left(\mathrm{m}^{2}\right)$. The abundance of macrozoobenthos genus is calculated by the formula:

$$
K=\frac{10.000(a)}{b}
$$

where:

$\mathrm{K}=$ abundance of macrozoobenthos (ind. $/ \mathrm{m}^{2}$ )

$10,000=$ conversion number from $\mathrm{cm}^{2}$ to $\mathrm{m}^{2}$.

$\mathrm{a}=$ the number of individuals of each genus

$\mathrm{b}=$ Ekman Grab's opening area $\mathrm{x}$ number of sampling points (n) $\left(\mathrm{cm}^{2}\right)$.

\section{b. Relative Abundance}

The relative abundance of individual macrozoobenthos was calculated using the formula:

$$
K R=\frac{n i}{N} x 100 \%
$$

where:

$\mathrm{KR}=$ relative abundance

ni $=$ numbers of individual of each genus

$\mathrm{N}=$ the total numbers of individual in the station

c. Diversity Index $\left(\mathrm{H}^{\prime}\right)$

The Diversity Index (H') was calculated based on Shannon-Wienner:

$$
H^{\prime}=-\left[\sum\left(\frac{n i}{N}\right) \ln \left(\frac{n i}{N}\right)\right]
$$

where:

$$
\begin{array}{ll}
\mathrm{H}^{\prime} & =\text { Diversity Index } \\
\mathrm{Ni} & =\text { Total individuals of each genus } \\
\mathrm{N} & =\text { Total genera }
\end{array}
$$

Criteria for the diversity index $\left(\mathrm{H}^{\prime}\right)$, namely:

$\mathrm{H}^{\prime}>3.0=$ high diversity

$1<\mathrm{H}^{\prime}<3=$ medium diversity

$\mathrm{H}^{\prime}<1=$ low diversity

d. Evenness Index (E)

Evenness Index (E) of genus was calculated using Simpson's formula as follows.

$$
\mathrm{E}=\mathrm{H}^{\prime} / \ln S
$$

where:

$\mathrm{E}=$ Evenness Index

$\mathrm{H}^{\prime}=$ Shannon-Wienner Diversity Index

$\mathrm{S}=$ Total genera

The value of the genus Evenness Index ranges from 0-1, where:

$\mathrm{e}>1=$ High evenness

$\mathrm{e}<1=$ Low evenness 
e. Dominance Index

The Dominance Index was calculated using the Simpson Dominance Index as follows:

$$
\mathrm{C}=\sum\left(\frac{n i}{N}\right)^{2}
$$

where:

$\mathrm{C}=$ Dominance Index

$\mathrm{ni}=$ Number of individuals of each genus

$\mathrm{N}=$ Number of individuals of all genera

The value of the dominance index based on Simpson was grouped into three criteria, namely:
$0<\mathrm{C} 0.30=$ Low dominance

$0.30<\mathrm{C} 0.60=$ Moderate dominance $0.60<\mathrm{C} 1.00=$ High dominance

\section{RESULTS AND DISCUSSION}

\section{Composition and Abundance}

There were ten genera of macrozoobenthos found. Station 1, riparian vegetation, found as many as six genera, while at station 2 , riparian with settlement area, found eight genera. The class Crustacea was more common, namely five genera $(50 \%)$, while the other five genera each found only one genus (10\%) (Table 1).

Table 1. Macrozoobenthos composition and abundance in the Berembang River

\begin{tabular}{llrrrr}
\hline Class & Genera & \multicolumn{2}{c}{ Abundance (ind./m $\mathrm{m}^{2}$ ) } & \multicolumn{2}{c}{ Relative abundance (\%) } \\
\cline { 2 - 5 } Crustacea & Station 1 & Station 2 & Station 1 & Station 2 \\
& Orchestia & 675 & 4350 & 9.47 & 23.35 \\
& Caridina & 0 & 150 & 0 & 1.01 \\
& Pyromaia & 150 & 150 & 2.1 & 1.01 \\
& Arhaphuroids & 75 & 225 & 1.05 & 1.52 \\
Insecta & Chironomus & 0 & 525 & 0 & 3.55 \\
Polychaeta & Namalycastis & 75 & 0 & 1.05 & 0 \\
Oligochaeta & Tubificoides & 0 & 150 & 0 & 1.01 \\
Bivalvia & Corbicula & 150 & 0 & 2.1 & 0 \\
Gastropoda & Pila & 5925 & 10050 & 83.15 & 68.02 \\
\hline
\end{tabular}

The highest abundance of macrozoobenthos at the two stations of Berembang River was Corbicula 5925 ind $/ \mathrm{m}^{2}$ at Station 1 and $10050 \mathrm{ind} / \mathrm{m}^{2}$ at Station 2. The genus Gammarus was also found to be abundant both at Station 1, (675 ind $\left./ \mathrm{m}^{2}\right)$ and at Station 2 (4350 ind $/ \mathrm{m} 2$ ) (Table 1). Thus, the relative abundance of these two genera was also higher than that of the other genera.

\section{Diversity, Evenness, and Dominance}

Macrozoobenthos diversity in the Berembang River was low, both at station 1 $\left(\mathrm{H}^{\prime}=0.63\right)$ and station $2\left(\mathrm{H}^{\prime}=0.83\right)$ with a mean $(\overline{\mathrm{x}})=0.73$. The Evenness value is also low at Station 1 , the value of $E=0.14$ and Station 2 , the value of $\mathrm{E}=0.16$ with a mean $(\bar{x})=0.15$. The low value of the two index values will cause the dominance index value (C) to be high, at Station $1=0.70$ and Station $2=0.93$ with a mean $(\bar{x})=0.81$ (Figure 2$)$. 
The dominance index value was obtained individuals without considering the from the proportion between the number of number of species in one station will be a individuals and the number of species found determining factor for the high value of the in one station so that the number of dominance index.

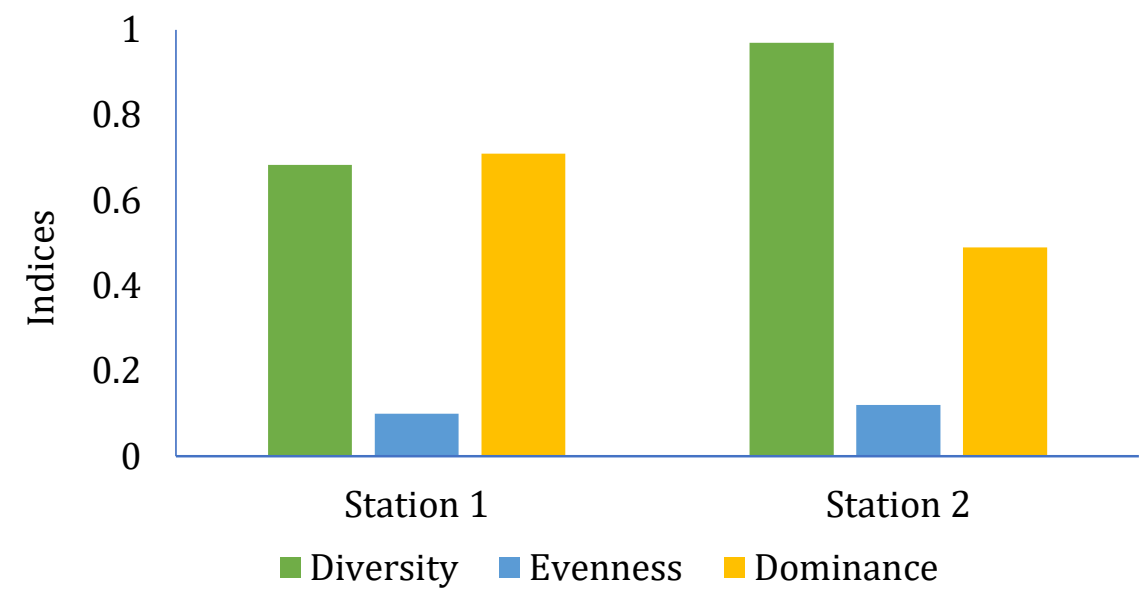

Figure 2. The ecological indices of Berembang River

The diversity index value in the stations was Corbicula. Corbicula was an Berembang River was low because there essential component in aquatic was one genus that dominated at each ecosystems, both as a component of the station. The low value of the diversity index food chain and as an indicator for in the Berembang River indicates that the monitoring water quality. Corbicula has condition of the river has begun to relatively sedentary even though the water experience ecological pressure. The quality has changed. Corbicula inhabits a stability of the ecosystem in the river has wide range of habitats with various water started to decline. In that case, the quality conditions with a long life span. The macrozoobenthos community living in the river begins to experience a decline in its dominance of Corbicula in Berembang distribution.

The Evenness index in Berembang River was also low, or the distribution of each species at each station was uneven. The dominance index obtained was classified as high, which means there was a dominant animal, based on the abundance value of the dominant animal at both River was also related to the sandy mud substrate found at stations 1 and 2. Sandy mud is the primary habitat of Corbicula. The ecological pressure was strongly suspected of coming from community activities in the Berembang River. At the time of sampling, a lot of garbage was found at the bottom and edge of the waters, and the number of water hyacinth plants shows 
that there are many pollutants in the river found at the two stations can be divided into flow (Laet et al., 2019). six categories, namely shredders, gathering

Functional Feeding Group (FFG) of collectors, deposit feeders, sub-surface Makrozoobenthos on Berembang River deposit feeders, filtering collectors, and Based on the results of the functional scrapers (Table 2).

feeding group (FFG), the macrozoobenthos

Table 2. FFG and composition of Macrozoobenthos at each station

\begin{tabular}{|c|c|c|c|c|c|c|c|}
\hline \multirow[t]{2}{*}{ No } & \multirow[t]{2}{*}{ FFG } & \multirow[t]{2}{*}{ Class } & \multirow[t]{2}{*}{ Family } & \multirow[t]{2}{*}{ Genera } & \multicolumn{2}{|c|}{ Station } & \multirow{2}{*}{$\begin{array}{c}\text { number } \\
\text { of ind. } \\
(\%)\end{array}$} \\
\hline & & & & & 1 & 2 & \\
\hline \multirow[t]{3}{*}{1.} & Shredders & Crustacea & Gammaridae & Gammarus & 9 & 46 & $61(20.9)$ \\
\hline & & & Talitridae & Orchestia & 0 & 2 & \\
\hline & & & Majidae & Pyromaia & 1 & 3 & \\
\hline \multirow[t]{2}{*}{2.} & Gathering & Insecta & Chironomidae & Chironomus & 1 & 0 & $5(1.71)$ \\
\hline & Collectors & Crustacea & Atyidae & Caridina & 2 & 2 & \\
\hline \multirow[t]{2}{*}{3.} & Deposit- & Crustacea & Tanaellidae & Arhaphuroids & 0 & 7 & 9 (3.09) \\
\hline & Feeders & Polychaeta & Nereididae & Namalycastis & 0 & 2 & \\
\hline 4. & $\begin{array}{l}\text { Sub-surface } \\
\text { deposit } \\
\text { feeders }\end{array}$ & Oligochaeta & Naididae & Tubificoides & 2 & 0 & $2(0.68)$ \\
\hline 5. & $\begin{array}{l}\text { Filtering } \\
\text { Collectors }\end{array}$ & Bivalvia & Corbiculidae & Corbicula & 79 & 134 & $213(72.9)$ \\
\hline 6. & Scrapers & Gastropoda & Ampullaridae & Pila & 0 & 1 & $1(0.34)$ \\
\hline \multicolumn{5}{|c|}{ Total } & 94 & 197 & $\begin{array}{r}291 \\
(100) \\
\end{array}$ \\
\hline
\end{tabular}

Shredders found in Berembang River were of the genera Gammarus (Family Gammaridae), Orchestia (Family

Talitridae), and Pyromaia (Family Majidae). The percentage of shredders at Station 2 was higher (29\%) than in Station 1 (11\%). Based on the percentage, only Gammarus and Pyromaia were found at Station 1, while at Station 2, all three genera were found. This condition indicates sufficient input of organic matter in the form of coarse particles originating from household organic waste and leaf litter from the riparian zone around Berembang River which accumulates downstream of the river. Shredders are the
FFG with the most genera found in Berembang River, with three genera consisting of Gammarus, Orchestia, and Pyromaia. The total number of shredders was 61 individuals from two stations . Next, filtering collectors were FFGs with the highest total number of individuals for the genus (Corbicula), which was 213 individuals from two Stations.

The genera included gatheringcollectors in Berembang River were Chironomus (Family Chironomidae) and Caridina (Family Atyidae). Chironomus was only found at Station 1 with a total of 1 individual, while the 
genus Caridina was found at Station 2 with a total of 4 individuals.

Chironomus obtain food from the decomposition of organic matter. The decomposition of organic matter has several functions, namely to mineralize organic matter, produce nutrients for plants and release organic substances into the environment so that it affects the growth of other organisms in the ecosystem. The availability of decomposed food in sufficient quantities strongly supports the growth of Chironomus larva larvae (Whatley et al., 2014). While the diet of the genus Caridina is dominated by green algae, other foods include algae (plankton), fine particulates, and detritus (Hamasaki et al., 2020).

The genera included as deposit feeders are Namalycastis (Family Nereididae) and Arhaphuroides (Family Tanaellidae). The percentage of deposit feeders at Station 2 (4\%) was not too different from Station 1 (1\%). It indicates that food availability in the form of fine particles in the riverbed sediment at the two stations was not significantly different. Station 2, which was closer to the downstream of the river, can affect the amount of sediment in the form of more muddy sediment. The percentage of deposit feeders was also more significant because more refined grains of sediment will retain more organic matter as food (North et al., 2014).

The genus of sub-surface depositfeeders found was Tubificoides (Family Naididae). Sub-surface deposit feeders were only found at Station 1 with a percentage of $2 \%$. This is probably related not only to the availability of food in the form of coarse particles, such as detritus but also to the dissolved oxygen levels in the water at each station. The availability of coarse particle food in the form of detritus at Station 1 was less than at Station 2. Station 1, which was in the upstream waters with an environmental profile of the plantation, was affecting the availability of coarse organic particulate matter. Oxygen levels obtained based on the measurement results ranged from $3.3-3.37 \mathrm{mg} / \mathrm{L}$, which indicates that the quality of dissolved oxygen in the waters of the Berembang River is unhealthy.

Filtering-collectors found in the Berembang River were of the genus Corbicula (Family Corbiculidae). The percentage of the presence of filtering collectors at Station 1 is higher (82\%) than at Station 2 (66\%). The higher percentage at Station 1 could be influenced by the station's location, which was close to plantations where the availability of food in the form of small organic particles was more than in Station 2. Small particles were 
available in almost all streams, including those in poor conditions. This type of organic matter was usually the result of algae degradation. Corbicula got its food by filtering dissolved organic particles in water bodies.

The genus included as scrapers were Pila (Family Ampullaridae). This genus was only found in Station 1 as many as one individuals. Scrapers obtain their food by scraping substrate from the surface of rocks and river vegetation. Like collectors, scrapers make use of organic materials available in the water. As long as the substrate was available in the rocks as a place for algae to grow, food for scrapers will also be fulfilled (Cummins, 2016).

The comparison of the FFG genus based on the number of individuals found at the two stations can be seen in Table 2 . Based on the FFG, at Station 1, there were four categories with a total of 94 individuals. The FFG categories found at Station 1 were filtering collectors 79 individuals (83\%), shredders ten individuals $(10.64 \%)$, gathering collectors three individuals (3.20\%), and sub-surface deposit feeders two individuals (2.12\%). Meanwhile, scrapers and deposit feeders were not found at Station 1. At Station 2, it was found that there were $5 \mathrm{FFG}$ categories with a total of 197 individuals. The FFG categories found at Station 2 were filtering collectors 134 individuals (68.02\%), shredders 51 individuals $(25.89 \%)$, deposit-feeders nine individuals (4.57\%), gathering collectors two individuals (1.01\%), and scrapers one individual (0.5\%). The sub-surface deposit feeders category was not found at Station 2.

\section{Physical-Chemical Parameters}

The results of measurements of physicochemical factors carried out in Berembang River include dissolved oxygen (DO), acidity (pH), transparency, temperature, and water flow can be seen in Table 3. The results show that the $\mathrm{pH}$ value of river water tends to be alkaline. Low transparency indicates the number of dissolved and suspended particles in the water, especially at Station 2, where there were settlements. Meanwhile, the measurement of dissolved oxygen (DO) at the study site ranged from $3.3-3.37 \mathrm{mg} / \mathrm{L}$. This value is also still following the class III water quality standard according to PP No 22 of 2021 for water biota. 
Table 3. Average of Water Quality Parameters and substrate type in Berembang River

\begin{tabular}{llrr}
\hline Parameter & Unit & $\mathbf{1}$ & Station \\
\cline { 3 - 4 } & & 7.8 & 7.16 \\
\hline $\mathrm{pH}$ & - & 28.0 & 28.08 \\
Temperature & ${ }^{\circ} \mathrm{C}$ & 0.90 & 0.78 \\
Transparenchy & $\mathrm{M}$ & 1.02 & 0.99 \\
Water flow & $\mathrm{m} / \mathrm{sec}$ & 3.77 & 3.32 \\
Dissolved Oxygen & $\mathrm{mg} / \mathrm{L}$ & sandy mud & sandy mud \\
Substrate type & Visual & &
\end{tabular}

Berembang River has a low transparency which indicates that the Berembang River has muddy and the water flow was also relatively slow. This condition was very suitable for Corbicula, which adapts by filtering out particles in the water.

\section{CONCLUSION}

The diversity and evenness of macrozoobenthos at both Berembang River stations was low $\left(\mathrm{H}^{\prime}=1.0\right.$ and $\left.\mathrm{E}=0.15\right)$, so the dominance was high $(\mathrm{C}=0.81)$ with dominant genera Corbicula and Gammarus. Functional Feeding Group macrozoobenthos found at both stations can be divided into six categories, namely shredders, gathering collectors, deposit feeders, sub-surface deposit feeders, filtering collectors, and scrapers.

\section{REFERENCES}

Ana, S., Miodrag, Đ., Marina, J., Pešić, V., Figures, I.N., Cabrera, S., ... An, S. Q. (2020). Macroinvertebrate diversity indices: A quantitative bioassessment of ecological health status of an oxbow lake in Eastern India. Journal of Coastal Research, 3(6),
3514-3524.

https://doi.org/10.5281/zenodo.1135973

Cabrera, S., Eurie Forio, M. A., Lock, K., Vandenbroucke, M., Oña, T., Gualoto, M., ... Der Heyden, C. Van. (2021). Variations in benthic macroinvertebrate communities and biological quality in the aguarico and coca river basins in the ecuadorian amazon. Water (Switzerland), 13(12). https://doi.org/10.339o/w13121692

Chen, Q., Sun, X., \& Yu, H. X. (2020). Study of macroinvertebrate functional feeding group abundance in tuanjie reservoir of Northeast China. Applied Ecology and Environmental Research, 18(3), 4435-4448. https://doi.org/10.15666/aeer/1803_4435444 8

Cummins, K. W. (2016). Combining taxonomy and function in the study of stream macroinvertebrates. Journal of Limnology, 75(1S), 235-241. https://doi.org/10.4081/jlimnol.2016.1373

Damanik-Ambarita, M. N., Lock, K., Boets, P., Everaert, G., Nguyen, T. H. T., Forio, M. A. E., ... Goethals, P. L. M. (2016). Ecological water quality analysis of the Guayas river basin (Ecuador) based on macroinvertebrates indices. Limnologica, 57 , 27-59. https://doi.org/10.1016/j.limno.2016.01.001

Ghosh, D., \& Kumar Biswas, J. (2015). Macroinvertebrate diversity indices: A quantitative bioassessment of ecological health status of an oxbow lake in Eastern India. J Adv Environ Health Res, 3(2), 78-90. Retrieved from http://jaehr.muk.ac.ir

Hamasaki, K., Nishimoto, S., Okada, M., Kimura, A., Otsubo, K., \& Dan, S. (2020). Dietary effects of phytoplankton and zooplankton on larval survival, duration and growth of four Caridina species (Decapoda: Caridea: Atyidae) under laboratory conditions. Crustacean Research, 49(o), 225-237. https://doi.org/10.18353/crustacea.49.o_225 
Hartwell, S. I., \& Fukuyama, A. K. (2015). The Effects of Sieve Size on Benthic Community Composition Analysis. Journal of Coastal Research, 31(6), 1531-1536. https://doi.org/10.2112/JCOASTRES-D-14ooo82.1

Laet, C., Matringe, T., Petit, E., \& Grison, C. (2019). Eichhornia crassipes: a Powerful Bioindicator for Water Pollution by Emerging Pollutants. Scientific Reports, 9(1), 1-10. https://doi.org/10.1038/s41598-019-43769-4

Madomguia, D., Togouet, S. H. Z., \& Fomena, A. (2016). Macro Invertebrates Functional Feeding Groups, Hilsenhoff Biotic Index, Percentage of Tolerant Taxa and Intolerant Taxa as Major Indices of Biological Assessment in Ephemeral Stream in SudanoSahelian Zone (Far-North, Cameroon). International Journal of Current Microbiology and Applied Sciences, 5(10), 792-8o6.

https://doi.org/10.20546/ijcmas.2016.510.08 6

Mangadze, T., Wasserman, R. J., Froneman, P. W., \& Dalu, T. (2019). Macroinvertebrate functional feeding group alterations in response to habitat degradation of headwater Austral streams. Science of the Total Environment, 695. https://doi.org/10.1016/j.scitotenv.2019.13391 o
North, C. A., Lovvorn, J. R., Kolts, J. M., Brooks, M. L., Cooper, L. W., \& Grebmeier, J. M. (2014). Deposit-feeder diets in the Bering Sea: Potential effects of climatic loss of sea icerelated microalgal blooms. Ecological Applications, 24(6), 1525-1542. https://doi.org/10.1890/13-0486.1

Pastorino, P., Zaccaroni, A., Doretto, A., Falasco, E., Silvi, M., Dondo, A., ... Bona, F. (2020). Functional feeding groups of aquatic insects influence trace element accumulation: Findings for filterers, scrapers and predators from the po basin. Biology, 9(9), 1-15. https://doi.org/10.3390/biology9090288

Tampo, L., Kaboré, I., Alhassan, E. H., Ouéda, A., Bawa, L. M., \& Djaneye-Boundjou, G. (2021). Benthic Macroinvertebrates as Ecological Indicators: Their Sensitivity to the Water Quality and Human Disturbances in a Tropical River. Frontiers in Water, 3(September), 1-17. https://doi.org/10.3389/frwa.2021.662765

Whatley, M. H., van Loon, E. E., Vonk, J. A., van der Geest, H. G., \& Admiraal, W. (2014). The role of emergent vegetation in structuring aquatic insect communities in peatland drainage ditches. Aquatic Ecology, 48(3), 267-283. https://doi.org/10.1007/s10452-0149482-3 